\title{
WATER CHEMISTRY IN THE CATCHMENT WITH HIGHEST RAINFALL AT GLOBAL SCALE AND INTENSIVE HUMAN ACTIVITY (NORTHEAST INDIA)
}

DOI: http://dx.doi.org/10.18509/GBP.2020.11

UDC: 556.166:504.61]:550.461(540)

\author{
Pawel Prokop \\ Department of Geoenvironmental Research, Institute of Geography and Spatial Organization, \\ Polish Academy of Sciences, Jana 22, 31-018 Kraków, Poland
}

\begin{abstract}
The subtropics within the monsoonal range are distinguished by seasonal rainfall and intensive human activity affecting stream water chemistry. This paper aims to determine spatio-temporal variations of stream water chemical elements in anthropogenically modified catchment located in the area with highest annual rainfall at global scale. The study was conducted in the Umiew catchment $\left(493.7 \mathrm{~km}^{2}\right)$ on the southern slope of the Meghalaya Plateau in Northeast India. The area encompasses two typical landforms with different land use of the southern slope: the grass covered hilly plateau with high population density and the forested deep canyon. The upper part of the Umiew catchment is built up of crystalline rocks that are covered by horizontally bedded sandstones and limestones in the lower part. The water sampling was conducted along the Umiew river in six sites during winter (baseflow) and monsoon season (fastflow) in 2014-2015. Numerous physico-chemical parameters were measured, including temperature, $\mathrm{pH}$, electrical conductivity (EC), dissolved organic carbon (DOC) and major ions. Chemical element concentrations were found to be low, with a total dissolved load (TDS) below $100 \mathrm{mg} \mathrm{L}^{-1}$. The facies pattern change from $\mathrm{Na}_{-} \mathrm{HCO}_{3}{ }^{-}$in the upper part to $\mathrm{Ca}-\mathrm{HCO}_{3}$ at the catchment outlet. Naturally low concentrations of chemical elements and very small seasonal differences associated with weathered bedrock, leached soils as well as forest vegetation. Human activity increases the spatial and temporal variation in the concentrations of chemical elements. In effect, water chemistry exhibited strongest control of anthropogenic impact in densely populated built-up areas in the upper part of the catchment. Low ion concentrations in the middle part of the catchment with deep forested canyon are a result of the crystalline deep weathered bedrock, high rainfall and forest vegetation. High ion concentrations at the river outlet are effect of intensive carbonate rocks weathering.
\end{abstract}

Keywords: subtropics, high rainfall, anthropogenic impact, land use, population

\section{INTRODUCTION}

The subtropics are distinguished by the distinct rainfall seasonality and long-term human activity. The result of the anthropogenic impact is a shift from natural to humandominated landscapes through deforestation for agriculture and mineral extraction as well as settlement development [1], [2]. Recent decades of accelerated population growth in many subtropical areas have caused further intensification of agriculture and expansion of built-up areas [3], [4]. In effect, within a relatively small area, there are often significant contrasts in population density and mosaics of land use and land cover (LULC) types affecting stream water chemistry [5], [6]. However, the complexity of natural and 
anthropogenic interactions, such as nonlinear hydrological processes, the intensification of present-day human activities, or catchment scale, complicate the distinction between the natural and anthropogenic impact on water chemistry [7].

The densely settled subtropical uplands constitute an example of areas where human activity is superimposed on changes induced by natural forces [8]. The Meghalaya Plateau located in Northeast India where the present study was conducted, is one of the rainiest inhabited environments on Earth, with more than 11,000 $\mathrm{mm}$ of precipitation recorded annually in Cherrapunji and Mawsynram. High monsoonal rains and hills with steep slopes cause that any human intervention in such a fragile environment can lead to rapid and long lasting changes [9], [10], [11]. Over recent decades, the rapid increase in population has generated intensification of farming systems and settlements, which are mirroring similar tendencies throughout the tropics [12]. The implications of human impact for water chemistry in subtropical regions can therefore be investigated and predicted on the basis of observations from the Meghalaya Plateau in Northeast India.

The presented paper attempts to determine the relative importance of natural processes (high rainfall, geology) as compared to human activities (LULC, population density) in the spatial and temporal transformation of the water chemistry within subtropical catchment.

\section{MATERIAL AND METHODS}

\section{Study area}

The study was conducted in the Umiew catchment $\left(493.7 \mathrm{~km}^{2}\right)$ on the southern slope of the Meghalaya Plateau (the North-Eastern extension of the Indian Peninsular Shield) which is exposed to humid southwest monsoon winds from the Bay of Bengal (Figure 1). The area encompasses two typical landforms with different LULC of the southern slope: the grass covered hilly plateau and the forested deep canyons. The upper part of the Umiew catchment is built up of deep weathered gneisses and quartzites intruded by granites [13]. Crystalline basement is covered near Cherrapunji and Mawsynram by resistant to weathering sandstones as well as to a lesser extent limestones.

The climate is monsoonal with the warm rainy season spanning from June to September and the dry cool winter [14]. The mean annual air temperature varies between $24^{\circ} \mathrm{C}$ in the Umiew outlet to $16.6^{\circ} \mathrm{C}$ in Shillong. The mean annual rainfall is strongly modified by the relief and varies from $6000 \mathrm{~mm}$ in the foothills to 11,000-12,000 $\mathrm{mm}$ in Cherrapunji and Mawsynram that are located at the spurs. The rainfall decreases with the distance from the edge of plateau to $2200 \mathrm{~mm}$ in Shillong.

The soils are nutrient deficient, due to the leaching resulting from high rainfall. Finer textured soils are found in the upper part of catchment, where was preserved the thicker weathered deposits [15]. In this part of the catchment, rice and potatoes are important cultivation crops [16]. The soils of sedimentary complex around Cherrapunji and Mawsynram are severely degraded with an armoured layer on the surface. The soils in adjoining canyons are rich in humus but shallow resulting from mass movements.

About $92 \%$ of the population is concentrated within the hilly plateau where the average density reached 211 inhabitants $\mathrm{km}^{-2}$ in 2011 [17]. The rest of the inhabitants are spread on the steep slopes of the canyon, where the average density is only 24 inhabitants $\mathrm{km}^{-2}$. 

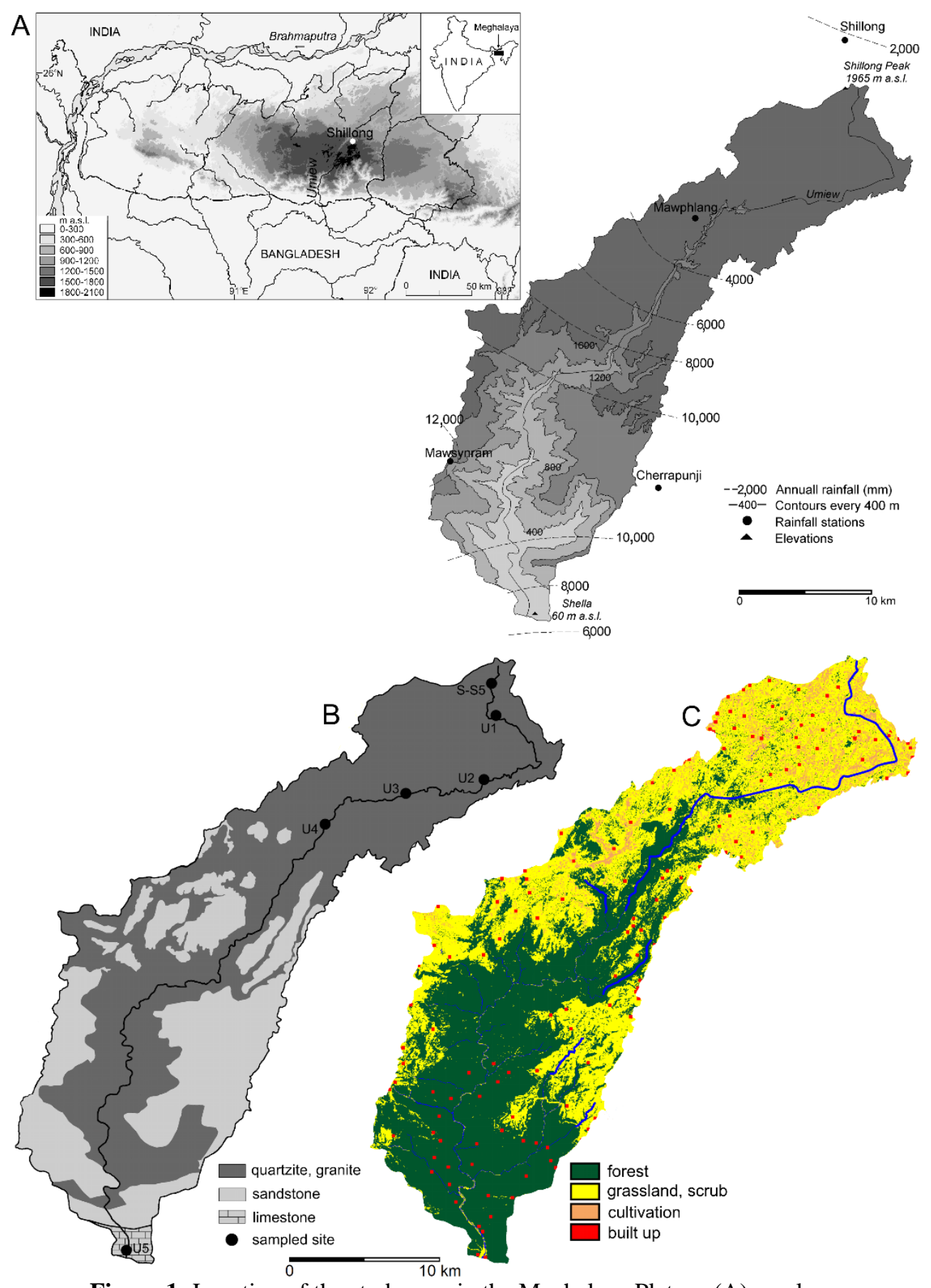

Figure 1: Location of the study area in the Meghalaya Plateau (A), geology and sampled sites (B), and LULC (C) in the Umiew catchment.

\section{Data collection and analysis}

The sampling was conducted in the Umiew catchment $\left(493.7 \mathrm{~km}^{2}\right)$ in five selected springs (S1-S5) and in five sites along the Umiew river (U1-U5) (Table 1). It was assumed that the inclusion of springs would help to explain the transformation of water chemistry downstream. Sampling, which consisted of measurements of physico-chemical parameters of water and collecting samples for chemical analysis, was conducted four times (i.e. twice during baseflow in the dry winter season (December 2014 and 2015) and twice during fastflow in the wet monsoon season (August 2014 and 2015). 
Table 1: General information on the sampling sites in the Umiew catchment, Meghalaya Plateau. Umiew catchment: S1-S5 - springs, U1-U5 - river.

\begin{tabular}{|c|c|c|c|c|c|c|c|c|}
\hline Site & $\begin{array}{l}\text { Site } \\
\text { elevation }\end{array}$ & Area & $\begin{array}{l}\text { Discharge } \\
\text { winter- } \\
\text { monsoon }\end{array}$ & $\begin{array}{l}\text { Population } \\
\text { density } \\
\text { in } 2011 \\
\end{array}$ & Forest & Grassland & $\begin{array}{l}\text { Cultivated } \\
\text { land }\end{array}$ & $\begin{array}{l}\text { Built } \\
\text { up }\end{array}$ \\
\hline No. & (m a.s.l.) & $\left(\mathrm{km}^{2}\right)$ & $\left(\mathrm{L} \mathrm{s}^{-1}\right)$ & $\begin{array}{c}\text { (inhabitants } \\
\mathrm{km}^{-2} \text { ) }\end{array}$ & $(\%)$ & $(\%)$ & $(\%)$ & $(\%)$ \\
\hline S1-S5 & 1850 & - & $0.2-0.8$ & $2=$ & - & - & - & \\
\hline U1 & 1780 & 10.8 & $490-1200$ & 1031 & 11 & 27 & 47 & 15 \\
\hline $\mathrm{U} 2$ & 1740 & 29.0 & $1100-2000$ & 800 & 12 & 25 & 53 & 10 \\
\hline $\mathrm{U} 3$ & 1680 & 59.3 & $2950-5300$ & 570 & 16 & 18 & 60 & 6 \\
\hline $\mathrm{U} 4$ & 1540 & 120.2 & $3000-50000$ & 260 & 22 & 28 & 47 & 3 \\
\hline U5 & 60 & 493.7 & $8000-1000000$ & 138 & 46 & 49 & 4 & 1 \\
\hline
\end{tabular}

Water temperature (T), $\mathrm{pH}$, and EC were measured in the field. Analyses of the main ions were conducted in a laboratory. Prior to analysis, samples were filtered through a Whatman glass microfiber GF/D with a filter size of $25 \mathrm{~mm}$ and pore size of $0.45 \mu \mathrm{m}$. Cations $\left(\mathrm{Ca}^{2+}, \mathrm{Mg}^{2+}, \mathrm{K}^{+}, \mathrm{Na}^{+}\right)$and anions $\left(\mathrm{Cl}^{-}, \mathrm{SO}_{4}{ }^{2-}, \mathrm{NO}_{3}{ }^{-}\right)$were determined by ion chromatography ICS3000 DIONEX. Limits of detection were: $\mathrm{Ca}^{2+}-0.4 \mathrm{mg} \mathrm{L}^{-1} ; \mathrm{Mg}^{2+}$, $\mathrm{Na}^{+}, \mathrm{SO}_{4}{ }^{2-}, \mathrm{NO}_{3}{ }^{-}, \mathrm{Cl}^{-}$, and $\mathrm{K}^{+}-0.1 \mathrm{mg} \mathrm{L}{ }^{-1}$. Bicarbonates $\left(\mathrm{HCO}_{3}{ }^{-}\right)$were determined using titration. Dissolved organic carbon was measured with the IL 550 TOC-TN by $\mathrm{HACH}$. The limit of detection was $0.1 \mathrm{mg} \mathrm{L}^{-1}$. Ionic (charge) balance error was expressed as the difference between cation and anion charges divided by their sum and multiplied by $100 \%$, not exceeding $10 \%$.

The LULC of the study catchment was prepared on the basis of a Landsat 8 multispectral satellite image with panchromatic sharpening, to spatial resolution of $15 \mathrm{~m}$ for 2015 . The population data were collected at village level for 2011 [17].

\section{RESULTS AND DISCUSSION}

\section{Role of natural factors and human activities in spatio-temporal changes of water chemistry in the Umiew catchment}

Temperature was the lowest in the springs and forested canyon in winter, while it increased progressively downstream in the monsoon season in the Umiew catchment (Table 2, Figure 2). Stream water was found to be alkaline during winter and acidic during the monsoon season. The exception was the outlet of the Umiew where the $\mathrm{pH}$ was always above 7 . Chemical element concentrations and stream discharge were usually negatively correlated, except $\mathrm{NO}_{3}{ }^{-}, \mathrm{SO}_{4}{ }^{2-}$, and DOC.

Concentrations of ions were low, as reflected in the EC and TDS, both of which ranged from 12 to $54 \mu \mathrm{S} \mathrm{cm}^{-1}$ and from 8 to $62 \mathrm{mg} \mathrm{L}^{-1}$, respectively. Despite low concentrations, significant spatial differences between sampled sites were apparent in both seasons. The lowest EC and TDS values were observed in the springs. These values increased downstream, but irregularly and showed two peaks. The first, lower peak (U1-U2) appeared where the Umiew traverse the most densely populated and built up upper part of the Umiew catchment. The second higher peak (U5) was noted at the outlet of the Umiew river underlined by carbonate rocks. A similar pattern was exhibited by $\mathrm{Ca}^{2+}$, $\mathrm{Mg}^{2+}$ and $\mathrm{HCO}_{3}{ }^{-}$ions in both seasons. The remaining ions $\left(\mathrm{K}^{+}, \mathrm{Na}^{+}, \mathrm{Cl}^{-}, \mathrm{NO}_{3}{ }^{-}\right.$and $\mathrm{SO}_{4}{ }^{2-}$,) showed one concentrations maximum in the upper, most densely populated part of the catchment (U1-U2). 
Table 2: Mean values of the physico-chemical variables during winter and monsoon seasons within the Umiew catchment. T - temperature, EC - electrical conductivity, TDS - total dissolved solids, and DOC - dissolved organic carbon.

\begin{tabular}{|c|c|c|c|c|c|c|}
\hline Winter & S1-S5 & U1 & U2 & U3 & U4 & U5 \\
\hline $\mathrm{T}\left({ }^{\circ} \mathrm{C}\right)$ & 13.1 & 14.7 & 16.8 & 14.6 & 14.1 & 19.7 \\
\hline $\mathrm{pH}$ & 7.1 & 7.5 & 7.0 & 7.6 & 7.9 & 7.9 \\
\hline $\mathrm{EC}\left(\mu \mathrm{S} \mathrm{cm}^{-1}\right)$ & 11.5 & 42.0 & 35.6 & 26.2 & 27.2 & 53.7 \\
\hline TDS $\left(\mathrm{mg} \mathrm{L}^{-1}\right)$ & 10.78 & 31.91 & 27.92 & 21.79 & 24.3 & 62.32 \\
\hline $\mathrm{Ca}^{2+}\left(\mathrm{mg} \mathrm{L}^{-1}\right)$ & 0.86 & 3.26 & 2.81 & 2.17 & 2.12 & 11.19 \\
\hline $\mathrm{K}^{+}\left(\mathrm{mg} \mathrm{L}^{-1}\right)$ & 0.31 & 1.29 & 1.08 & 0.80 & 1.08 & 0.62 \\
\hline $\mathrm{Mg}^{2+}\left(\mathrm{mg} \mathrm{L}^{-1}\right)$ & 0.20 & 0.79 & 0.60 & 0.48 & 0.48 & 1.13 \\
\hline $\mathrm{Na}^{+}\left(\mathrm{mg} \mathrm{L}^{-1}\right)$ & 1.73 & 3.79 & 3.32 & 2.84 & 3.33 & 2.66 \\
\hline $\mathrm{Cl}^{-}\left(\mathrm{mg} \mathrm{L}^{-1}\right)$ & 0.98 & 3.78 & 1.70 & 1.93 & 2.25 & 1.45 \\
\hline $\mathrm{HCO}_{3}^{-}\left(\mathrm{mg} \mathrm{L}^{-1}\right)$ & 5.54 & 14.12 & 16.69 & 10.76 & 12.26 & 41.98 \\
\hline $\mathrm{NO}_{3}^{-}\left(\mathrm{mg} \mathrm{L}^{-1}\right)$ & 0.34 & 3.44 & 0.73 & 1.67 & 1.56 & 0.98 \\
\hline $\mathrm{SO}_{4}{ }^{2-}\left(\mathrm{mg} \mathrm{L}^{-1}\right)$ & 0.65 & 1.00 & 0.55 & 0.74 & 0.72 & 2.28 \\
\hline DOC $\left(\mathrm{mg} \mathrm{L}^{-1}\right)$ & 0.01 & 0.32 & 0.43 & 0.37 & 0.40 & 0.21 \\
\hline Monsoon & S1-S5 & U1 & U2 & U3 & U4 & U5 \\
\hline $\mathrm{T}\left({ }^{\circ} \mathrm{C}\right)$ & 18.6 & 20.3 & 20.7 & 20.9 & 21.6 & 23.7 \\
\hline $\mathrm{pH}$ & 6.2 & 6.5 & 6.6 & 6.4 & 6.6 & 7.3 \\
\hline $\mathrm{EC}\left(\mu \mathrm{S} \mathrm{cm}^{-1}\right)$ & 11.5 & 36.0 & 31.8 & 25.4 & 23.5 & 49.8 \\
\hline TDS $\left(\mathrm{mg} \mathrm{L}^{-1}\right)$ & 8.20 & 23.84 & 21.08 & 19.09 & 18.10 & 45.96 \\
\hline $\mathrm{Ca}^{2+}\left(\mathrm{mg} \mathrm{L}^{-1}\right)$ & 0.77 & 3.26 & 2.77 & 2.49 & 2.22 & 6.64 \\
\hline $\mathrm{K}^{+}\left(\mathrm{mg} \mathrm{L}^{-1}\right)$ & 0.14 & 0.58 & 0.70 & 0.61 & 0.48 & 0.55 \\
\hline $\mathrm{Mg}^{2+}\left(\mathrm{mg} \mathrm{L}^{-1}\right)$ & 0.19 & 0.68 & 0.47 & 0.45 & 0.41 & 0.72 \\
\hline $\mathrm{Na}^{+}\left(\mathrm{mg} \mathrm{L}^{-1}\right)$ & 1.16 & 1.96 & 1.91 & 1.76 & 1.67 & 1.82 \\
\hline $\mathrm{Cl}^{-}\left(\mathrm{mg} \mathrm{L}^{-1}\right)$ & 0.60 & 2.06 & 1.60 & 1.56 & 1.53 & 1.55 \\
\hline $\mathrm{HCO}_{3}{ }^{-}\left(\mathrm{mg} \mathrm{L}^{-1}\right)$ & 4.19 & 5.85 & 6.35 & 5.01 & 4.59 & 29.45 \\
\hline $\mathrm{NO}_{3}^{-}\left(\mathrm{mg} \mathrm{L}^{-1}\right)$ & 0.22 & 7.49 & 5.63 & 5.57 & 4.58 & 5.23 \\
\hline $\mathrm{SO}_{4}{ }^{2-}\left(\mathrm{mg} \mathrm{L}^{-1}\right)$ & 0.44 & 1.71 & 1.39 & 1.39 & 1.32 & 1.58 \\
\hline $\mathrm{DOC}\left(\mathrm{mg} \mathrm{L}^{-1}\right)$ & 2.23 & 2.15 & 2.10 & 2.15 & 2.06 & 2.24 \\
\hline
\end{tabular}

The increase of EC, TDS, and most of the major ions in the densely settled landscapes suggests the weathering of anthropogenic infrastructure, which is termed the 'urban stream syndrome' [18], [19]. It covers the dissolution of concrete reinforced embankments of channelized streams (bridgeheads, walls, gabions); concrete pipes and gutters, roofs, walls of buildings, bridges, and roads [20], [21]. Nitrate levels also suggest anthropogenic influences because they exceed $1.0 \mathrm{mg} \mathrm{L}^{-1}$ [22]. Elevated concentrations of $\mathrm{NO}_{3}{ }^{-}$and $\mathrm{SO}_{4}{ }^{2-}$ may reflect the effects of domestic sewage supply [19]. In addition, some households presumably led to a higher $\mathrm{NO}_{3}{ }^{-}$and $\mathrm{SO}_{4}{ }^{2-}$ input of farm manure from pigs, goats, and poultry kept by farmers, as observed in other tropical regions [23]. Concentrations of $\mathrm{Cl}^{-}$and $\mathrm{Na}^{+}$can rise due to a flushing effect of domestic sewage effluents [24]. Anthropogenic sources of $\mathrm{Cl}^{-}$may also affect the polyvinyl chloride (PVC) gutters and pipes used as part of building infrastructure [25]. Study of water chemistry in this part of the catchment indicated that within grasslands, vegetation biomass with dense roots is sufficiently high to increase the ion pool in the topsoil and than in the surface water [26]. In contrast, cultivated land only moderately affected water chemistry, through mobilization of ions during soil tillage in the monsoon season. Despite a significant human impact, chemical concentrations in the studied part of the catchment did not exceed the desirable limits set by the WHO [27]. 

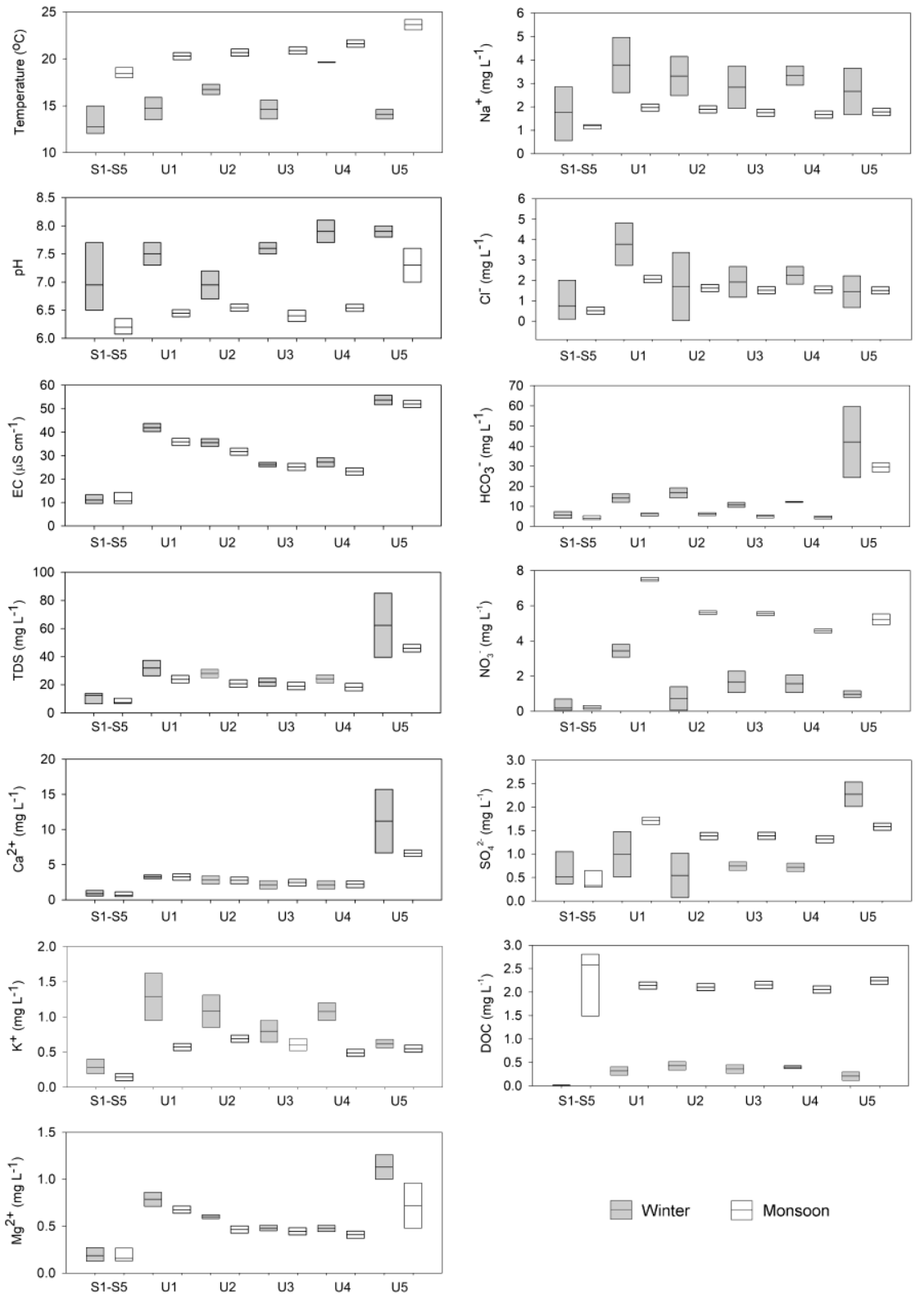

$\square$ Winter $\quad \square$ Monsoon

Figure 2: Comparison of surface water physico-chemical properties during winter and monsoon seasons for the Umiew catchment. Sites as in Table 1. T - temperature, EC - electrical conductivity, TDS - total dissolved solids, and DOC - dissolved organic carbon.

The line within the box represents the median.

In the middle course of the Umiew river, in the forested canyon (U4), a decrease of concentrations of most ions, especially $\mathrm{NO}_{3}{ }^{-}$and $\mathrm{SO}_{4}{ }^{2-}$ associated with anthropogenic sources, is visible. This is also reflected in low EC and TDS values. Forest soils of the Umiew catchment are poor in chemicals [16]. Fast litter decomposition and nutrient uptake lead to the ion stock being held mainly in living biomass. Self-cleaning of the river is additionally facilitated by very high rainfall and low population density.

Concentrations of DOC showed strong seasonality with highest values in all sampled sites (U1-U5) including springs (S1-S5) during the monsoon season. They are the effect of various processes in the Umiew catchment. The high DOC concentration in springs might be an effect of the water table rising in the rainy season, resulting from increasing macropore flow as soil moisture increases, giving rise to a hydrologic flushing of DOC 
from the topsoil to springs [28]. Elevated values of DOC in the upper part of the catchment reflect cultivation practices that stimulate the mobilization of the organic $\mathrm{C}$ pool in the soil [4] as well as a lack of sanitation infrastructure in the built up areas [24]. The increase in DOC concentrations in forest catchments is related to high rainfall that generates runoff and already has been documented in numerous studies from the tropical zone [29], [30].

\section{Hydrochemical facies and mechanisms controlling water chemistry in the Umiew catchment}

The springs and outlet of the Umiew river showed $\mathrm{Na}^{+}-\mathrm{HCO}_{3}{ }^{-}$and $\mathrm{Ca}^{2+}-\mathrm{HCO}_{3}{ }^{-}$water type respectively in both seasons (Figure 3). All other sampled sites had the $\mathrm{Na}^{+}-\mathrm{HCO}_{3}{ }^{-}$ water type in the winter. The facies pattern was more differentiated during the monsoon season. Anthropogenic activities and human infrastructure were additional sources of $\mathrm{Ca}^{2+}, \mathrm{NO}_{3}{ }^{-}$and to some extent $\mathrm{SO}_{4}{ }^{2-}$ ions [21] that changed the water type to $\mathrm{Ca}^{2+}-\mathrm{NO}_{3}{ }^{-}$ in the upper part of the catchment. The seasonal enrichment of sampled sites with $\mathrm{Cl}^{-}$ during the monsoon was also visible.

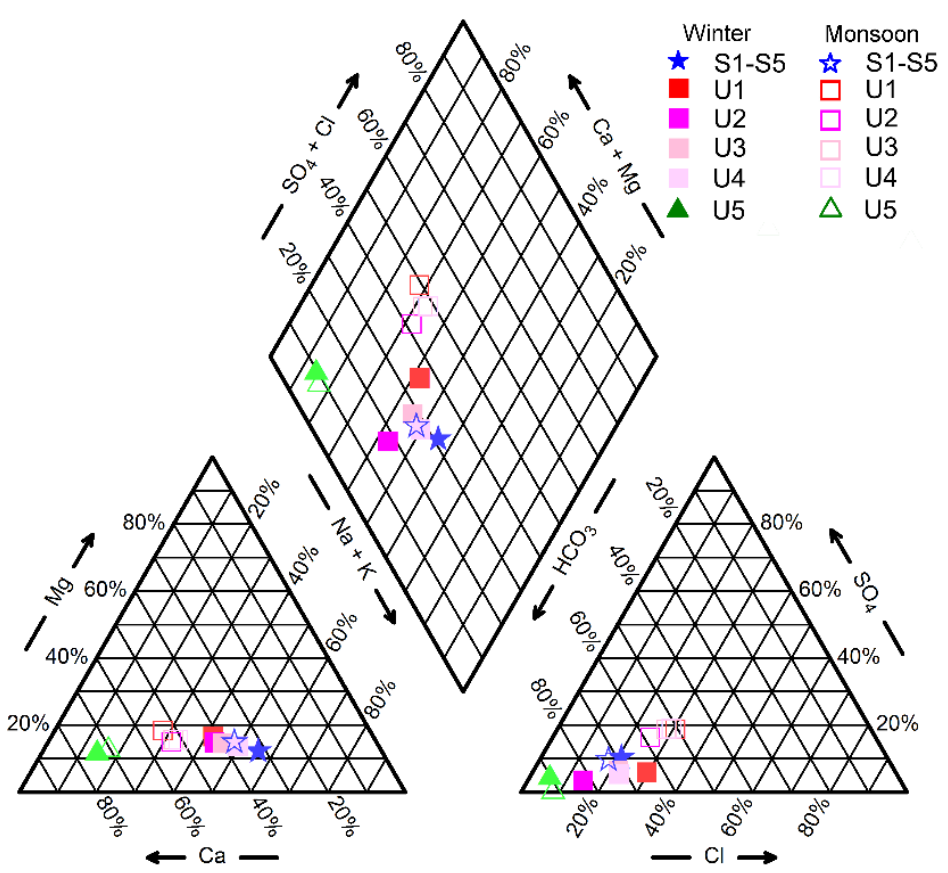

Figure 3: The water facies for the Umiew catchment.

A plot of $\mathrm{Na}^{+} /\left(\mathrm{Na}^{+}+\mathrm{Ca}^{2+}\right)$ against TDS provides information about the relative importance of the major mechanisms controlling water chemistry in the Umiew catchment (Figure 4) [31]. The plot shows transition from the atmospheric precipitation to the rock dominance sectors from springs to the outlet of the Umiew river. Samples from the monsoon season fall at the margin of the region that encompasses most water of the earth's surface. These samples with very low TDS in the upper part of the catchment suggest that weathered cover is well leached and significant additional amount of $\mathrm{Na}^{+}$and $\mathrm{Ca}^{2+}$ has been derived from anthropogenic sources and rainfall [21], [32]. In contrast, the main source of major ions at the Umiew outlet is carbonate rock weathering. 


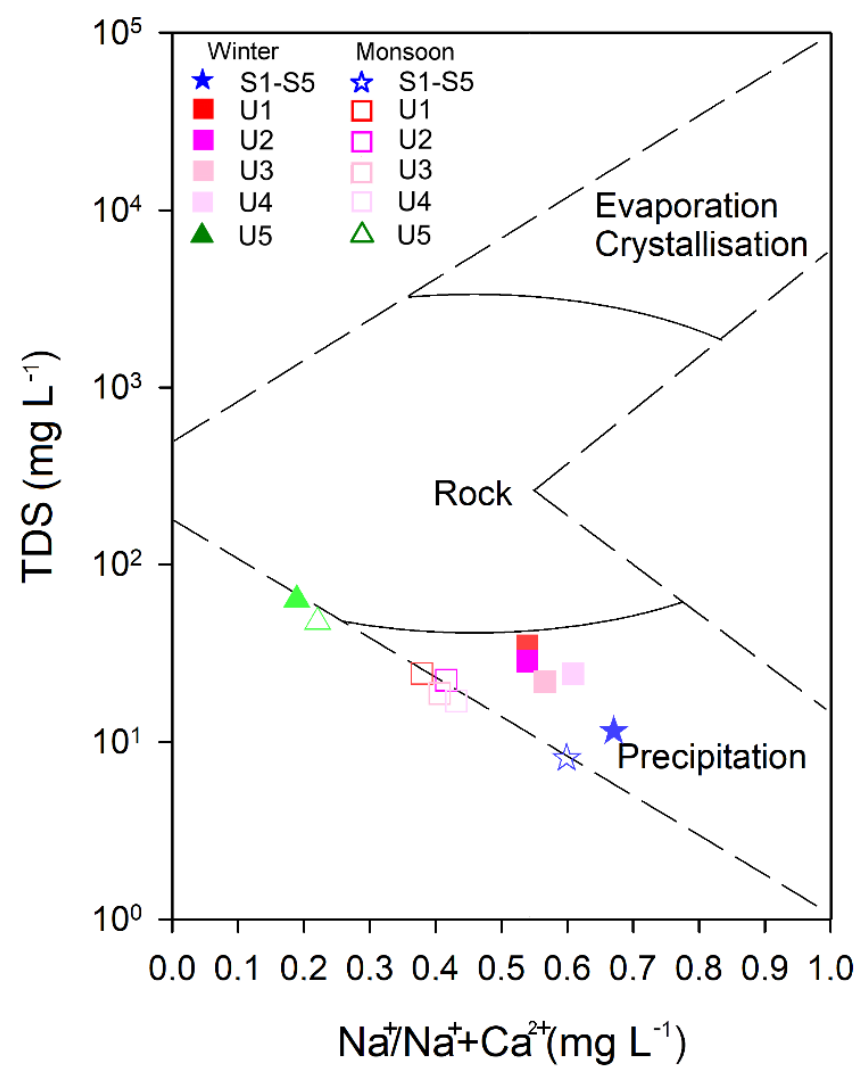

Figure 4: Gibbs diagram classification of the surface water in the Umiew catchment.

\section{CONCLUSIONS}

Water chemistry of subtropical catchment in monsoonal climate with highest rainfall at global scale characterized naturally low concentrations of chemical elements and very small seasonal differences associated with weathered bedrock, leached soils as well as forest vegetation. Human activity (population density, LULC) overlapped with the natural features (geology, high rainfall) of the environment and increased the spatial and temporal variation in the concentrations of chemical elements. In effect, water chemistry exhibited dominance of natural or anthropogenic features in different parts of the subtropical catchment. Moderate to high ion concentrations in the deforested upper part of the catchment indicates that densely populated built-up areas exhibited the strongest control on stream water chemistry in both seasons. Low ion concentrations in the middle part of the catchment with deep forested canyon are mainly a result of the underlying geochemistry associated with crystalline deep weathered bedrock, high rainfall and forest vegetation. Such an ion pattern is closely related to natural environmental conditions in the investigated subtropical region. High ion concentrations at the river outlet are effect of intensive carbonate rocks weathering.

\section{Acknowledgments}

This paper was completed as a part of the cooperation between Polish Academy of Sciences, Warsaw, and Indian National Science Academy, New Delhi. Author would like to thank Łukasz Wiejaczka, Hiambok J. Syiemlieh, Jane E. Warjri and Rafał Kozłowski, who helped with sample collection and analyses. 


\section{REFERENCES}

[1] Pongratz J., Reick C., Raddatz T., Claussen M.A. Reconstruction of global agricultural areas and land cover for the last millennium. Global Biogeochemical Cycles, vol. 22, 2008.

[2] Hansen M.C., Potapov P.V., Moore R., Hancher M., Turubanova S.A., Tyukavina A., Thau D., Stehman S.V., Goetz S.J., Loveland T.R., Kommareddy A. High-resolution global maps of 21st-century forest cover change. Science, vol. 342, pp 850-853, 2013.

[3] McKee L.J., Eyre B.D., Hossain S., Pepperell P.R. Impacts of climate, geology and humans on spatial and temporal variability in nutrient geochemistry in the subtropical Richmond River catchment. Marine Freshwater Research, vol. 52, pp 235-248, 2001.

[4] Da Silva D.M.L., Ometto J.P.H.B., de Lobo G.A., de Lima W.P., Scaranello M.A., Mazzi E., da Rocha H.R. Can land use changes alter carbon, nitrogen and major ion transport in subtropical Brazilian streams? Scientia Agricola, vol. 64, pp 317-324, 2007.

[5]. Girija T.R., Mahanta C.; Chandramouli V. Water quality assessment of an untreated effluent impacted urban stream: The Bharalu tributary of the Brahmaputra River, India. Environmental Monitoring and Assessment, vol. 130, pp 221-236, 2007.

[6] Silva J.S.O., da Cunha Bustamante M.M., Markewitz D., Krusche A.V., Ferreira L.G. Effects of land cover on chemical characteristics of streams in the Cerrado region of Brazil. Biogeochemistry, vol. 105, pp 75-88, 2011.

[7] Allan J.D. Landscapes and riverscapes: The influence of land use on stream ecosystems. Annual Review of Ecology, Evolution, and Systematics, vol. 35, pp 257-284, 2004.

[8]. Nyssen J., Poesen J., Deckers J. Land degradation and soil and water conservation in tropical highlands. Soil and Tillage Research, vol. 103, pp 197-202, 2009.

[9] Ramakrishnan P.S. Shifting agriculture and sustainable development: An interdisciplinary study from North-Eastern India. Parthenon Publications, Carnforth, UK, 1992.

[10] Prokop P., Suliga I. Two thousand years of iron smelting in the Khasi Hills, Meghalaya, North East India. Current Science, vol. 104, pp 761-768, 2013.

[11] Rączkowska Z., Bucała-Hrabia A., Prokop P. Geomorphological and sedimentological indicators of land degradation (Meghalaya Plateau, NE India). Land Degradation \& Development, vol. 29, pp 2746-2759, 2018.

[12] Vliet V.N., Mertz O., Heinimann A., Langanke T., Pascual U., Schmook B., Adams C., Schmidt-Vogt D., Messerli P., Leisz S., Castella J.C., Jorgensen L., Birch-Thomsen T., Hett C., Bech-Bruun T., Ickowitz A., Vu K.C., Yasuyuki K., Fox J., Padoch C., Dressler W., Ziegler A.D. Trends, drivers and impacts of changes in swidden cultivation in tropical forest-agriculture frontiers: A global assessment. Global Environmental Change, vol. 22, pp 418-429, 2012.

[13] Migoń P., Prokop P. Landforms and landscape evolution in the Mylliem granite area, Meghalaya Plateau, Northeast India. Singapore Journal of Tropical Geography, vol. 34, pp 206228, 2013.

[14] Prokop P., Walanus A. Variation in the orographic extreme rain events over the Meghalaya Hills in northeast India in the two halves of the twentieth century. Theoretical and Applied Climatology, vol. 121, pp 389-399, 2015.

[15] Prokop P., Bhattacharyya A. Reconnaissance of quaternary sediments from Khasi Hills, Meghalaya. Journal of the Geological Society of India, vol. 78, pp 258-262, 2011.

[16] Prokop P., Kruczkowska B., Syiemlieh H.J., Bucała-Hrabia A. Impact of topography and sedentary swidden cultivation on soils in the hilly uplands of North-East India. Land Degradation \& Development, vol. 29, pp 2760-2770, 2018.

[17] Government of India. Census of India 2011. New Delhi, Government of India, 2011. 
[18] Fitzpatrick M.L., Long D.T., Pijanowski B.C. Exploring the effects of urban and agricultural land use on surface water chemistry, across a regional watershed, using multivariate statistics. Applied Geochemistry, vol. 22, pp 1825-1840, 2007.

[19] Halstead J.A., Kliman S., Berheide C.W., Chaucer A., Cock-Esteb A. Urban stream syndrome in a small, lightly developed watershed: A statistical analysis of water chemistry parameters, land use patterns, and natural sources. Environmental Monitoring and Assessment, vol. 186, pp 3391-3414, 2014.

[20] Wright I.A., Davies P.J., Findlay S.J., Jonasson O.J. A new type of water pollution: Concrete drainage infrastructure and geochemical contamination of urban waters. Marine Freshwater Research, vol. 62, pp 1355-1361, 2011.

[21] Connor N.P., Sarraino S., Frantz D.E., Bushaw-Newton K., MacAvoy S.E. Geochemical characteristics of an urban river: Influences of an anthropogenic landscape. Applied Geochemistry, vol. 47, pp 209-216, 2014.

[22] Morgan R.P., Kline K.M. Nutrient concentrations in Maryland non-tidal streams. Environmental Monitoring and Assessment, vol. 178, pp 221-235, 2011.

[23] Recha J.W., Lehmann J., Walter M.T., Pell A., Verchot L., Johnson M. Stream water nutrient and organic carbon exports from tropical headwater catchments at a soil degradation gradient. Nutrient Cycling in Agroecosystems, vol. 95, pp 145-158, 2013.

[24]. Martinelli L.A., Krusche A.V., Victoria R.L., Camargo P.B.D., Bernardes M., Ferraz E.S., Moraes J.M.D., Ballester M.V. Effects of sewage on the chemical composition of Piracicaba River, Brazil. Water Air \& Soil Pollution, vol. 110, pp 67-79, 1999.

[25] Davies P.J., Wright I.A., Jonasson O.J., Findlay S.J. Impact of concrete and PVC pipes on urban water chemistry. Urban Water Journal, vol. 7, pp 233-241, 2010.

[26] Prokop P., Wiejaczka Ł., Syiemlieh H. J., Kozłowski R. Response of water chemistry to long-term human activities in the nested catchments system of subtropical Northeast India. Water, vol. 11, pp 988, 2019.

[27] WHO. Guidelines for drinking water quality. WHO: Geneva, Switzerland, 2011.

[28] Johnson M.S., Lehmann J., Selva E.C., Abdo M., Riha S., Couto E.G. Organic carbon fluxes within and streamwater exports from headwater catchments in the Southern Amazon. Hydrologicla Processess, vol. 20, pp 2599-2614, 2006.

[29] Goller R., Wilcke W., Fleischbein K., Valarezo C., Zech W. Dissolved nitrogen, phosphorus, and sulfur forms in the ecosystemfluxes of amontane forest in Ecuador. Biogeochemistry, vol. 77, pp 57-89, 2006.

[30] Jacobs S.R., Breuer L., Butterbach-Bahl K., Pelster D.E., Rufino M.C. Land use affects total dissolved nitrogen and nitrate concentrations in tropical montane streams in Kenya. Science of the Total Environment, vol. 603, pp 519-532, 2017.

[31] Gibbs R.J. Mechanisms controlling world water chemistry. Science, vol. 170, pp 1088-1090, 1970.

[32] Padmalal D., Remya S.I., Jyothi S.J., Baijulal B., Babu K.N., Baiju R.S. Water quality and dissolved inorganic fluxes of $\mathrm{N}, \mathrm{P}, \mathrm{SO} 4$, and $\mathrm{K}$ of a small catchment river in the southwestern coast of India. Environmental Monitoring and Assessment, vol. 184, pp 1541-1557, 2012. 